\title{
Anestesi Posisi Prone untuk Pengangkatan Tumor Torakal Posterior Pasien Pediatri dengan Malnutrisi Kronis dan Gangguan Metabolik
}

\author{
Kulsum*), Iwan Abdul Rachman ${ }^{* *}$, MM. Rudi Prihatno***), Zafrullah Khany Jasa*), Fachrul Jamal ${ }^{*}$ ) \\ ${ }^{*}$ Departemen Anestesiologi dan Terapi Intensif Fakultas Kedokteran Universitas Syiah Kuala - RSUD Zainoel \\ Abidin Banda Aceh, ${ }^{* *}$ Departemen Anestesiologi dan Terapi Intensif Fakultas Kedokteran Universitas Padjadjaran \\ RSUP Dr. Hasan Sadikin Bandung, ${ }^{* * *}$ Departemen Anestesiologi dan Terapi Intensif Fakultas Universitas Jend. \\ Soedirman RSUD Prof. Dr. Margono Purwokerto
}

\begin{abstract}
Abstrak
Malnutrisi kronis adalah suatu keadaan dimana tubuh mengalami gangguan dalam penggunaan zat gizi untuk pertumbuhan, perkembangan dan aktivitas. Gangguan metabolik yaitu kondisi adanya kelainan proses metabolisme pada tubuh akibat defisiensi enzim atau hormon. Posisi prone pada neuroanestesi pediatrik tulang belakang dilakukan untuk mencapai tekanan perfusi otak dan tulang belakang yang normal. Tujuan kasus ini membahas pengelolaan neuroanestesi pediatrik pada posisi prone dengan adanya kelainan malnutrisi kronis merupakan hal yang rumit sehingga diperlukan manajemen agar menghasilkan outcome yang baik. Anak laki laki, 8 tahun, $15 \mathrm{~kg}$, $102 \mathrm{~cm}$, benjolan di punggung belakang yang keluar merembes cairan dengan diameter $7 \mathrm{~cm}$ sejak lahir, kelemahan anggota gerak, buang air besar dan buang air kecil tertahan. Dilakukan VP-shunt 2 minggu lalu. Premedikasi dengan midazolam dan fentanyl. Induksi menggunakan propofol dan ada penambahan saat laringoskopi dan intubasi. Fasilitas intubasi dengan atracurium. Pemeliharaan anestesi dengan $\mathrm{O}_{2}+$ udara + sevofluran $2 \%$ dengan fraksi oksigen $50 \%+$ propofol dan rocuronium bolus intravena. Monitoring tanda vital (tekanan darah, denyut jantung, frekuensi nafas, saturasi oksigen, jumlah dan warna urin) serta end tidal $\mathrm{CO}_{2}$. Hasil setelah pengangkatan tumor selama 2 jam hemodinamik relatif stabil, tekanan darah 100-120/60-80 mmHg. Pasien ditempatkan di Pediatric Intensive Care Unit. Simpulan: diperlukan manajemen neuroanestesi pediatrik untuk menangani kasus malnutrisi kronik dan gangguan metabolik pada pengangkatan tumor torakal posterior agar menghasilkan outcome yang baik.
\end{abstract}

Kata kunci: malnutrisi kronis; gangguan metabolik; posisi prone; pediatrik

JNI 2019; 8 (3): 180-89

\section{Prone Position Anesthesia for Posterior Thoracal Tumor Removal Pediatric Patient with Chronic Malnutrition and Metabolic Disorder}

\begin{abstract}
Chronic malnutrition is a condition where the body experiences a disruption in the use of nutrients for growth, development and activity. Metabolic disorders are conditions in which there are abnormal metabolic processes in the body due to enzyme or hormone deficiency. The prone position in pediatric spinal neuroanesthesia is performed to achieve normal cerebral and spinal perfusion pressure. The purpose of this case is to discuss the management of pediatric neuroanesthesia in the complicated prone position in order to produce good outcomes. Boy, 8 years old, $15 \mathrm{~kg}, 102 \mathrm{~cm}$, a lump in the back that came out seeping fluid with a diameter of $7 \mathrm{~cm}$ from birth, weakness in limbs, bowel movements and urinary retention. Performed a VP shunt 2 weeks ago. The premedication method uses midazolam and fentanyl. Induction uses propofol and there are additions during laryngoscopy and intubation. Intubation facilities with atracurium. Maintenance of anesthesia with $\mathrm{O}_{2}+$ air + sevoflurane $2 \%$ with $50 \%$ oxygen fraction + propofol and intravenous rocuronium bolus. Monitoring vital signs (blood pressure, heart rate, respiratory rate, oxygen saturation, amount and color of urine) and end tidal $\mathrm{CO}_{2}$. Tumor removal results for 2 hours hemodynamically are relatively stable, blood pressure $60-80 / 40-50 \mathrm{mmHg}$. Patients are admit to the Pediatric Intensive Care Unit. Conclusion: pediatric neuroanesthesia management is needed to handle chronic malnutrition and metabolic disorders in the removal of posterior thoracic tumors in order to produce good outcomes.
\end{abstract}

Key words: chronic malnutrition; metabolic disorders; prone position

JNI 2019; 8 (3): 180-89 


\section{Pendahuluan}

Hasil Riset Kesehatan Dasar (Riskesdas) tahun Malnutrisi kronis 2013 menyatakan bahwa persentase gizi buruk di Indonesia pada tahun 2013 adalah 37,\%. ${ }^{1}$ Kekurangan energi protein (KEP) adalah manifestasi dari kurangnya asupan protein dan energi, dalam makanan seharihari yang tidak memenuhi Angka Kecukupan Gizi (AKG) dan biasanya juga diserta adanya kekurangan dari beberapa nutrien lainnya. Malnutrisi primer bila kejadian KEP akibat dari kekurangan asupan nutrisi, yang pada umumnya didasari oleh masalah sosial ekonomi, pendidikan serta rendahnya pengetahuan di bidang gizi. Malnutrisi sekunder bila kondisi masalah nutrisi seperti diatas disebabkan karena adanya penyakit utama, seperti kelainan bawaan, infeksi kronis ataupun kelainan pencernaan dan metabolik, yang mengakibatkan kebutuhan nutrisi meningkat, penyerapan nutrisi yang turun dan meningkatnya kehilangan nutrisi. Makanan yang tidak adekuat, akan menyebabkan mobilisasi berbagai cadangan makanan untuk menghasilkan kalori demi penyelamatan hidup, dimulai dengan pembakaran cadangan karbohidrat kemudian cadangan lemak serta protein dengan melalui proses katabolik. Jika terjadi stres katabolik (infeksi) maka kebutuhan akan protein akan meningkat, sehingga dapat menyebabkan defisiensi protein relatif, kalau kondisi ini terjadi pada saat status gizi masih diatas -3 SD (-2SD-3SD), maka disebut kwashiorkor (malnutrisi akut"decompensated malnutrition"). Pada kondisi ini penting peranan radikal bebas dan antioksidan. Bila stres katabolik ini terjadi pada saat status gizi dibawah -3 SD, maka disebut marasmik-kwashiorkor. Bila kondisi kekurangan ini terus dapat teradaptasi sampai dibawah -3 SD maka disebut marasmik (malnutrisi kronik/compensated malnutrition). Keadaan pada malnutrisi dapat terjadi: gangguan pertumbuhan, atrofi otot, penurunan kadar albumin serum, penurunan hemoglobin, penurunan sistem kekebalan tubuh, penurunan berbagai sintesa enzim. ${ }^{1,2}$

Tumor thorakal posterior merupakan salah satu dari tumor medulla spinalis pada daerah cervical pertama hingga sacral. Berdasarkan lokasinya, tumor medula spinalis dapat dibagi menjadi dua kelompok, yaitu tumor intradural dan ekstradural, di mana tumor intradural itu sendiri dibagi lagi menjadi tumor intramedular dan ekstramedular. Penyebab tumor medula spinalis primer sampai saat ini belum diketahui secara pasti. Beberapa penyebab yang mungkin dan hingga saat ini masih dalam tahap penelitian adalah virus, kelainan genetik, dan bahan-bahan kimia yang bersifat karsinogenik. Adapun tumor sekunder (metastasis) disebabkan oleh sel-sel kanker yang menyebar dari bagian tubuh lain melalui aliran darah yang kemudian menembus dinding pembuluh darah, melekat pada jaringan medula spinalis yang normal dan membentuk jaringan tumor baru di daerah tersebut. ${ }^{4}$ Pasien ini juga mengalami kelainan spina bifida, yaitu kelainan neural tube (neural tube defect) yang terjadi akibat kegagalan neural tube untuk menutup dengan sempurna. Jika sakus tersebut berisi medulla spinalis dinamakan meningomielokel. Angka kejadian 1 dalam 1000 kelahiran. ${ }^{3,4}$ Pada kasuskasus lainnya, defek yang terjadi mungkin sangat ringan seperti spina bifida okulta. Malformasi yang menyertai, khususnya hidrosefalus, anansefalus dan clubfoot umum terdapat. Jika bagian otak mengalami protrusion ke dalam sakus, terjadi meningoensefalokel. ${ }^{4}$ Penggunaan suplemen folic acid 400 mikrogram/hari sebelum hamil dan 800 mikrogram/ hari selama kehamilan penting untuk menurunkan risiko terjadinya defek neural tube seperti spina bifida. Folic acid (folinic acid, folacin, pteroyglutamic acid) terdiri dari bagian-bagian pteridin, asam para aminobenzoat dan asam glutamat. ${ }^{5}$

\section{Kasus}

\section{Anamnesis}

Seorang anak laki laki berusia 8 tahun dengan berat badan $15 \mathrm{~kg}$, dan tinggi badan $102 \mathrm{~cm}$, mengeluh kelemahan anggota gerak bawah, buang air besar dan buang air kecil tertahan, benjolan di punggung dengan diameter $7 \mathrm{~cm}$ dan dari benjolan tersebut merembes cairan yang dirasakan sejak lahir. Pasien lahir secara seksio sesarea atas indikasi kehamilan lewat waktu dengan berat badan lahir 3.200 gram. 
Riwayat pemberian ASI tidak tuntas dan riwayat imunisasi tidak lengkap. Pasien telah dipasang VP-shunt 2 minggu yang lalu dan telah dilakukan debridement pada saat usia pasien 6 bulan.

\section{Pemeriksaan Fisik}

Pemeriksaan fisik didapatkan jalan nafas bebas, tidak terdengar suara tambahan apapun. Pernafasan gerak dada simetris, frekuensi napas 20x/menit, tidak terlihat sesak nafas rhonki dan wheezing tidak dijumpai. Hemodinamik dijumpai tekanan darah 96/62 mmHg, frekuensi nadi 118 kali per menit, capillary refill $<2$ detik, $\mathrm{SpO}_{2}$ $98 \%$. Defisit neurologis dijumpai paraparese inferior dengan kekuatan motorik 4444/4444, tidak dijumpai penurunan kekuatan motorik pada ekstremitas atas. Pasien juga mengalami inkontinensia urin dan alvi. Kesadaran penuh dan tidak ada defisit neurologis pada saraf kranialis lainnya.

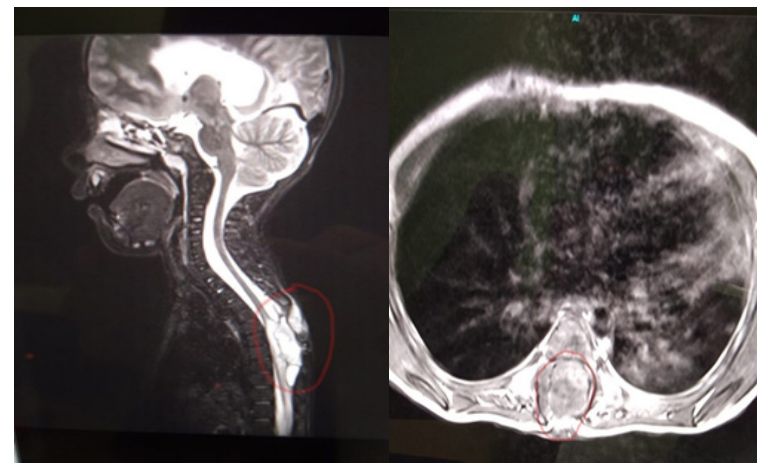

Gambar 1. MRI Spine

\section{Pemeriksaan Radiologi}

Magnetic Resonance Imaging (MRI) : Massa solid kistik ukuran $4,7 \times 2,7 \times 2 \mathrm{~cm}$ intra dural yang meluas ke ekstra dural sampai kutis subkutis dengan thoraks sisi posterior dijumpai edema medulla spinalis, defek di prosesus setinggi thorakal 7,8 serta stenosis spinalis setinggi Th6 - Th9.

Rontgen thorak: tidak ada kelainan pada jantung dan paru.

\section{Pemeriksaan Laboratorium}

$\mathrm{Hb}: 10,1 \mathrm{~g} / \mathrm{dl}, \mathrm{Ht}: 27 \%$, L: 10.000, T: 566.000. Na: $142 \mathrm{mmol} / \mathrm{L}, \mathrm{K}: 4,2, \mathrm{Cl}: 97$, kadarguladarah $96 \mathrm{mg} / \mathrm{dl}$

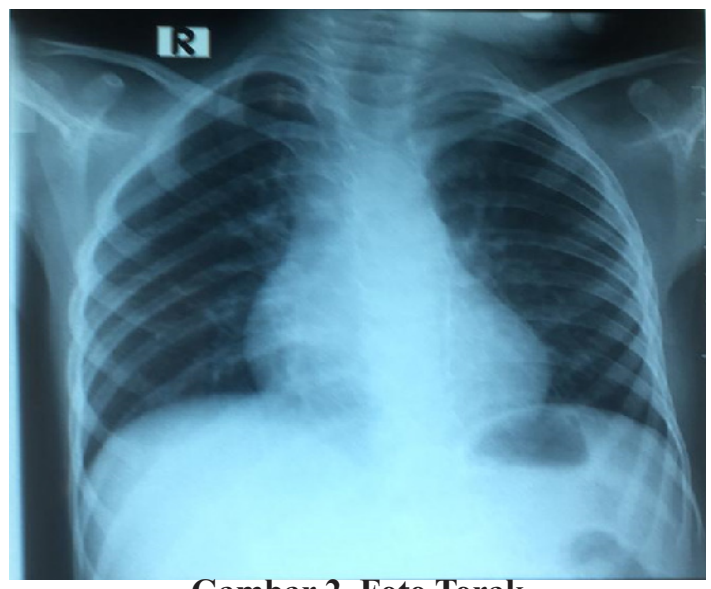

Gambar 2. Foto Torak

\section{Pengelolaan Anestesi}

Preoperasi kebutuhan rumatan cairan pasien sudah terpenuhi di ruangan. Pasien sudah dirawat selama satu minggu dalam pengawasan bagian anak untuk pencegahan infeksi. Pasien dimasukkan ke dalam kamar operasi dengan terpantau saat itu hemodinamik prainduksi yaitu tekanan darah 104/60 $\mathrm{mmHg}$, frekuensi nadi 110 kali per menit, frekuensi napas 20 kali per menit dan saturasi $\mathrm{O}_{2} 98 \%$. Seharusnya pasien sudah diberikan premedikasi di ruangan. Koinduksi menggunakan midazolam $1 \mathrm{mg}$ dan fentanyl $30 \mathrm{mcg}$. Induksi menggunakan propofol $30 \mathrm{mg}$, rocuronium $1 \mathrm{mg}$. Saat tindakan laringoskopi dan intubasi dan tidak didapati gejolak hemodinamik lebih dari 20\%. Pemasangan nasogastric tube (NGT) dilakukan setelah intubasi. Pemeliharaan anestesi dengan $\mathrm{O}_{2}+$ udara + sevofluran 1,5-2\% dengan fraksi oksigen $50 \%$ dan penambahan propofol $10 \mathrm{mg}$ dan rocuronium $10 \mathrm{mg}$. Monitoring tanda-tanda vital selama operasi dilakukan dengan alat non-invasif meliputi EKG, tekanan darah arteri arterial blood pressure (ABP), $\mathrm{SpO}_{2}, \mathrm{EtCO}_{2}$, suhu, dan urin. Selama operasi, tekanan darah berkisar antara 100120/60-80 mmHg, denyut jantung berkisar 70 $100 \mathrm{x} /$ menit, saturasi oksigen $95-100 \%$. Pada saat operasi sistol menurun tapi masih dalam batas normal dan laju nadi naik karena perdarahan yang terjadi. Kontrol ventilator dengan modus Asist Volume TV 120, $\mathrm{FiO}_{2} 50 \%$, RR 20x/menit, end tidal $\mathrm{CO}_{2}$ menunjukkan $\mathrm{PaCO}_{2} 35 \mathrm{mmHg}$. Jumlah urin $30 \mathrm{cc}$ dalam 2 jam, dan warna urin kuning jenih. Operasi reseksi tumor berlangsung selama 2 jam. Perdarahan selama operasi sekitar $10 \%$ 


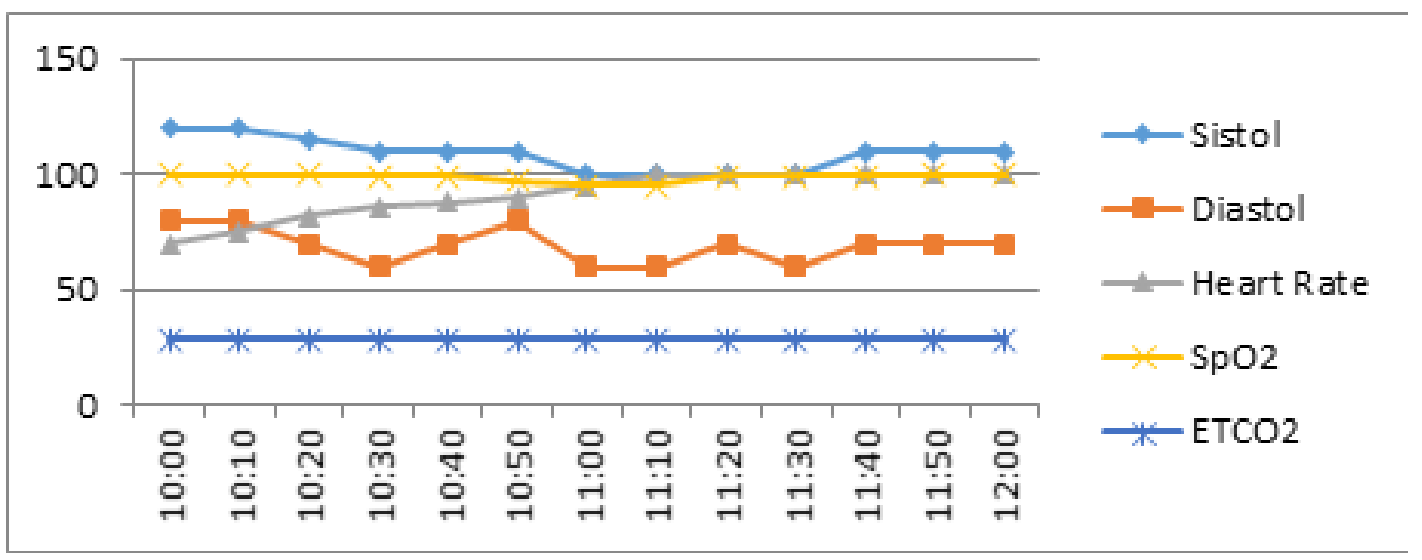

Grafik 3. Grafik Tanda Vital Selama Operasi

atau sekitar $100 \mathrm{ml}$ dari Estimated Blood Volume $=75 \times 15 \mathrm{~kg}=1.125 \mathrm{ml}$ darah, selama operasi hemodinamik relatif stabil. Pemberian cairan $50 \mathrm{cc} /$ jam ditambah cairan untuk mengganti perdarahan $300 \mathrm{ml}$ dan urin $30 \mathrm{ml}$ dalam 2 jam, Cairan untuk mengganti penguapan selama operasi 2 jam yaitu 2x2x15=60 ml. Jadi total cairan $\mathrm{NaCl} 0,45 \%$ dengan dextrose 5\% yang diberikan $490 \mathrm{ml}$ selama 2 jam. Tindakan tidak banyak manipulasi selama operasi.

\section{Pengelolaan Pascabedah}

Setelah operasi pasien dirawat di Pediatrik Intensive Care Unit (PICU). Obat pasca operasi yang diberikan adalah novalgin $300 \mathrm{mg}$ bolus dan sisanya $700 \mathrm{mg}$ dimasukkan dalam cairan rumatan dan di drip, ceftriakson $750 \mathrm{mg}$ per 12 jam intravena. Kebutuhan cairan $50 \mathrm{cc} / \mathrm{jam}$ dengan jenis cairan $\mathrm{NaCl} 0,45 \%$ dengan dextrose $5 \%$. Diet diberikan sonde feeding melalui NGT fr. 8 berisi tim sari encer 3 x $150 \mathrm{cc}$ ditambah susu formula 5 x $100 \mathrm{cc}$.

\section{Pembahasan}

Malnutrisi adalah suatu keadaan defisiensi, kelebihan atau ketidakseimbangan protein energi dan nutrien lain yang dapat menyebabkan gangguan fungsi pada tubuh. Secara umum malnutrisi terbagi atas dua bagian yaitu undernutrisi dan overnutrisi. Undernutrisi atau keadaan defisiensi terdiri dari marasmus, kwashiorkor, serta marasmic-kwashiorkor.
Sedangkan overnutrisi atau kelebihan nutrisi lebih dikenal dengan obesitas. ${ }^{1,2}$ Penyebab marasmic kwashiorkor dapat dibagi menjadi dua penyebab yaitu malnutrisi primer dan malnutrisi sekunder. Malnutrisi primer adalah keadaan kurang gizi yang disebabkan oleh asupan protein maupun energi yang tidak adekuat. Malnutrisi sekunder adalah malnutrisi yang terjadi karena kebutuhan yang meningkat, menurunnya absorbsi dan/ atau peningkatan kehilangan protein maupun energi dari tubuh. ${ }^{2}$ Diagnosis Kekurangan Energi Protein ditegakkan dengan berdasarkan tanda dan gejala klinis serta pengukuran antropometri. Anak didiagnosis gizi buruk apabila: $\mathrm{BB} / \mathrm{TB}<-3$ $\mathrm{SD}$ atau $70 \%$ dari median (marasmus), edema pada kedua punggung kaki sampai seluruh tubuh (kwashiorkor: $\mathrm{BB} / \mathrm{TB}>-3 \mathrm{SD}$ atau marasmic kwashiorkor: $\mathrm{BB} / \mathrm{TB}<-3 \mathrm{SD}$ ).

Jika BB/TB tidak dapat diukur, gunakan tanda klinis berupa anak tampak sangat kurus (visible severe wasting) dan tidak mempunyai jaringan lemak bawah kulit terutama pada kedua bahu, lengan, pantat, paha, tulang iga terlihat jelas, dengan atau tanpa adanya edema. Anak - anak dengan $\mathrm{BB} / \mathrm{U}<60 \%$ belum tentu gizi buruk, karena mungkin anak tersebut pendek, sehingga tidak terlihat sangat kurus. Anak seperti itu tidak membutuhkan perawatan di rumah sakit, kecuali jika ditemukan penyakit lain yang berat. ${ }^{2}$ Pasien ini mengalami malnutrisi kronik yang ditandai dengan nilai $\mathrm{BB} / \mathrm{U}<-2 \mathrm{SD}$ dan $\mathrm{TB} / \mathrm{U}<-2 \mathrm{SD}$, namun belum mencapai <-3D. Berdasarkan 
protokol Enhanced Recovery After Surgery (ERAS), manajemen nutrisi harus dilakukan pada pasien yang direncanakan untuk tindakan operasi supaya recovery setelah operasi dapat berlangsung cepat dan optimal. Manajemen nutrisi termasuk menilai status nutrisi, aturan puasa dan nutrisi pascaoperasi. ${ }^{6}$

Tatalaksana umum malnutrisi energi protein: (1) penilaian triase anak dengan gizi buruk dengan tatalaksana syok pada anak dengan gizi buruk; (2) jika ditemukan ulkus kornea, beri vitamin A dan obat tetes mata kloramfenikol/ tetrasiklin dan atropin; tutup mata dengan kasa yang telah dibasahi dengan larutan garam normal, dan balutlah. Jangan beri obat mata yang mengandung steroid; (3) jika terdapat anemia berat, diperlukan penanganan segera; (4) penanganan umum meliputi 10 langkah dan terbagi dalam 3 fase yaitu: fase stabilisasi, fase transisi, fase rehabilitasi dan fase tindak lanjut.1 Saat preoperasi, dokter anestesi harus mengatur aturan puasa termasuk karbohidrat. Aturan puasa berupa (1) minum minuman sampai 2 jam sebelum operasi; (2) makan makanan biasa sampai 6 jam sebelum operasi. ${ }^{6}$

Manajemen nutrisi dari bagian gizi bisa berupa (1) suplemen nutrisi oral 10-14 hari pada pasien dengan risiko undernutrition atau dengan ingestan $<60 \%$ kebutuhan energi; (2) nutrisi enteral: pasien dengan risiko nutrisi berat diberikan 1014 hari sebelum operasi elektif besar (tindakan bisa ditunda jika dibutuhkan setelah diskusi medikobedah), pasien dengan intake oral $<60 \%$ dari kebutuhan energi lebih dari 10 hari sebelum operasi, pasien yang diperkirakan tidak ada intake lebih dari 7 hari sebelum operasi tanpa tandatanda malnutrisi; (3) nutrisi parenteral: pada pasien dengan kontraindikasi (obstruksi intestinal atau ileus, syok berat, iskemik intestinal, muntah berat, peritonitis). ${ }^{6}$ Pada pasien ini kebutuhan total kalori $80-100 \mathrm{kkal} / \mathrm{kgBB}=(80-100) \mathrm{x}$ $15 \mathrm{~kg}=1200 \mathrm{kkal}$. Total kalori yang dibutuhkan dalam pemberian $75-80 \%$ dari kebutuhan total kalori seharusnya $(1200 \mathrm{kkal})=960 \mathrm{kkal}$. Kebutuhan karbohidrat 55-60\% dari total kalori yang dibutuhkan $(960 \mathrm{kkal})=528-576 \mathrm{kkal}$. Kebutuhan protein $25 \%=240$ kkal. Kebutuhan lemak $15 \%=144$ kkal. Kebutuhan pemberian diet post operasi pada pasien ini melalui sonde feeding dengan total pemberian $950 \mathrm{kkal}$ per hari $(80 \%$ dari total kalori 1200$)$, dibagi dalam $3 \times 150 \mathrm{cc}$ tim sari encer dan $5 \times 100 \mathrm{cc}$ susu formula enteralkid. Pemberian nutrisi pada anak dengan malnutrisi kronis harus diberikan secara bertahap, dimulai $50-80 \%$ kalori total harian atau disebut dengan fase stabilisasi dan transisi. Hal ini dilakukan untuk mencegah terjadinya refeeding syndrome yaitu sindroma dengan gangguan klinis dan metabolik yang timbul akibat rehabilitasi nutrisi yang agresif pada pasien penderita malnutrisi berat. ${ }^{1}$

Gangguan metabolik yang terjadi pada malnutrisi kronik adalah dengan keluarnya hormone kortisol, glukagon dan katekolamin yang meningkat, dan keluarnya hormone insulin yang menurun sehingga akan terjadi keadaan hiperglikemik. Pada fase akut, kadar insulin serum mengalami depresi dan hormon pertumbuhan (GH) meningkat di antara anak-anak dengan malnutrisi. Kortisol mengikat protein serum; oleh karena itu, hipoalbuminaemia akan menyebabkan peningkatan kadar kortisol plasma bebas yang dapat berkontribusi pada toleransi glukosa dan edema abnormal yang terlihat pada anak dengan malnutrisi kronis. ${ }^{7}$

Dalam keadaan stress, katekolamin dan glukagon meningkat, dan akibatnya glikogen hati dan otot dipecah (glikogenolisis) sehingga glukosa dilepas ke sirkulasi. Glikogen merupakan sumber glukosa yang terbatas, tidak lama setelah itu produksi glukosa di hati juga meningkat oleh perangsangan katekolamin dan glukagon. Sumber glukoneogenesis berasal terutama dari asam amino otot, dan terpenting alanine dan glutamin. Proses pembuatan glukoneogenesis energinya berasal bukan dari glukosa, melainkan dari pemecahan lemak tubuh. Pada penyakit bedah yang serius, proses adaptasi perubahan dasar yang terlihat pada kondisi pembedahan seperti trauma dan sepsis yang membuat kebutuhan glukosa meningkat. Hal ini didapat dari asam amino yang dihasilkan dari pemecahan protein otot. Pada penyakit bedah yang serius, terjadi malnutrisi kronis dimana proses adaptasi ini tidak efektif, 
dan terjadi kanibalisasi otot untuk menyediakan alanine dan glutamin yang menjadi bahan mentah produksi glukosa. Hiperglikemi ini dihasilkan untuk memenuhi energi otak, luka dan tempattempat infeksi yang cedera. Pada pasien dengan sepsis berat memiliki keadaan hipermetabolisme, proteolisis, dan ekspansi cairan ekstraseluler yang tidak bisa dijelaskan oleh respon neuroendokrin setelah bedah mayor atau trauma sedang.

Respons metabolik terhadap pembedahan menjadi ebb phase yang ditandai oleh hipovolemia disusul oleh respon simpatis dan adrenal. Fase berikutnya flow phase, yaitu pasien mengalami kehilangan protein dalam kecepatan yang berlebihan. Flow phase durasinya bergantung pada keparahan trauma, dan keparahan flow phase ini digantikan oleh fase konvalesensi. Pada fase ini cadangan protein dan energi yang hilang pada periode dini pasca trauma diisi kembali. Energetika perioperatif selama 2 minggu pasca operasi mayor, pasien mengalami defisit energi yang cukup besar. Hanya separuh dari kebutuhan energi dipenuhi oleh dekstrosa intravena dan makanan. Untuk mencapai imbang energi, cadangan lemak, dan glikogen. Manajemen metabolik pasien yang menjalani operasi antara lain pemberian antibiotik profilaktik dan tindakan preventif untuk mencegah thrombosis vena akan membantu kelancaran penyembuhan setelah operasi. Pada saat operasi, ahli anestesi membuat hipovolemik dapat dicegah, dan pengendalian tekanan darah, nadi, volume urin dan dapat mengurangi respon endokrin terhadap trauma operasi, sehingga mengurangi fase injury dan mempersingkat masa rawat.

Manajemen selama fase pascabedah dengan memberikan analgesic untuk mengurangi nyeri pascabedah. Pemberian opioid sistemik tidak memiliki efek modifikasi penting terhadap respon endokrin, namun efeknya sangat penting dalam mengurangi atau menghapus nyeri pascabedah, mengurangi kebutuhan jantung dan mengendalikan spasme otot. Energi dan protein yang dipasok melalui enteral dan parenteral bisa mencegah kehilangan protein setelah operasi besar. Respon penyembuhan luka didukung oleh nutrisi pasca bedah. Insulin yang ditambahkan ke regimen TPN dan pemberian growth hormone dapat mengurangi kehilangan protein dan mempertahankan komposisi tubuh dan menambah kekuatan genggam tangan. ${ }^{8}$

Terdapat banyak perubahan sistem fisiologis pada anak dengan malnutrisi kronis, yang secara langsung dan tidak langsung mempengaruhi disposisi obat yang biasanya digunakan. Perubahan patofisiologis terjadi sebagai akibat dariketidakseimbangan antara pasokan nutrisi dan kebutuhan. Total Body Water (TBW) bertambah seiring dengan meningkatnya derajat malnutrisi. Konsentrasi dari obat yang larut lemak akan meningkat pada target organ yang pada akhirnya akan memperpanjang efek farmakodinamik. ${ }^{7}$ Hipoproteinemia sering terjadi pada pasien malnutrisi kronis yang mengalami gangguan metabolik. Albumin plasma dan fraksi glikoprotein yang mengikat obat akan berkurang dalam hal ini. Secara teori, sebagai hasil dari pengurangan ini terdapat peningkatan free-drug fraction pada plasma dari obat yang terikat kuat dengan protein dan anak dengan malnutrisi kronis yang mengalami perubahan metabolic ini akan memberi respons secara bervariasi dan berisiko meningkatkan toksisitas. Gangguan metabolic pada malnutrisi kronis juga dikaitkan dengan berbagai tingkat malabsorpsi usus dan dikaitkan dengan atrofi vili mukosa jejunal sehingga hal ini dapat mengganggu penyerapan obat. ${ }^{7}$ Perubahan lain yang dapat terjadi adalah level albumin yang rendah, pergeseran distribusi dari ruangan intravaskular ke interstisial dan pelepasan hormon yang meningkatkan destruksi metabolisme albumin. Level serum hemoglobin dan trace element seperti magnesium dan fosfor merupakan tiga indikator kimia tambahan. Hemoglobin dapat mengindikasikan kapasitas angkut oksigen sedangkan magnesium dan fosfor dapat mengindikasikan gangguan jantung, saraf dan neuromuskular. ${ }^{9}$ Perubahan fisiologis pada pasien malnutrisi kronis berhubungan erat dengan disposisi abnormal yang mungkin membutuhkan modifikasi dosis obat. Telah dilaporkan perubahan pada ikatan protein harus diperhatikan saat penggunaan klinis obat dengan protein-binding rate $\geq 80 \%$. Protein binding rate dari fentanyl adalah $84,4 \%$, sedangkan morfin hanya $20-36 \%$ 
dan oksikodon adalah $45 \%$. Hal yang paling perlu untuk diperhatikan adalah monitor level albumin serum selama terapi menggunakan fentanyl. ${ }^{10}$

Sedasi preoperatif sebelum induksi pada pasien ini diindikasikan untuk menekan respon stres. Pada keadaan response stres terjadi hiperkatabolik, pemecahan lemak dan protein, dan peningkatan kadar glukosa darah. Pada pasien ini sudah terjadi malnutrisi kronik dimana sudah sangat hiperkatabolik sehingga diperlukan dosis obat premedikasi yang lebih kecil dari dosis karena sedikitnya ikatan protein yang lepas (binding protein). Premedikasi pada anak sangat diperlukan untuk meredakan kecemasan dan rasa takut pada diri anak. Kecemasan dapat menyebabkan anak menangis atau meronta yang akan meningkatkan tekanan intrakranial secara signifikan dan pada pasein ini sudah ada peningkatan intrakranial sebelumnya. Pada pasien ini diberikan sedasi dengan midazolam. Midazolam sering dipilih sebagai sedasi karena tidak ada depresi pernapasan atau perubahan pada $\mathrm{PaCO}_{2}$ pada anak. Pemberian dapat dilakukan peroral, intravena atau inhalasi. Stress operasi mengeluarkan hormon kortisol, glukagon, insulin, dan katekolamin. Dimana yang meningkat itu hormon kortisol, glukagon dan yang menurunkan hormon insulin, keadaan ini semua meningkatkan kadar glukosa darah sehingga terjadi keadaan hiperglikemik. Dalam keadaan malnutrisi kronis lebih banyak terjadi peemcahan protein dan lemak. Artinya protein yang beredar dalam darah sedikit, sehingga diperlukan dosis obat lebih kecil.

Penatalaksanaan untuk sebagian besar tumor medulla spinalis adalah dengan pembedahan. Tujuannya adalah untuk menghilangkan tumor secara total dengan menyelamatkan fungsi neurologis secara maksimal. ${ }^{11}$ Manajemen anestesi pada kasus tumor ini adalah menjaga spinal perfusion pressure. Sebelumnya pasien ini juga terdapat hidrosefalus dan sudah dilakukan pemasangan VP-shunt untuk menurunkan tekanan intrakranial dan melakukan proteksi otak. Pengaturan aliran darah sumsum tulang belakang mirip dengan aliran darah otak. Pembuluh darah sumsum tulang belakang dipengaruhi oleh perubahan $\mathrm{PCO}_{2}$ dan hipoksia.

Hiperkapnia meningkatkan aliran darah. Autoregulasi menjaga regional dan total aliran darah sumsum tulang belakang konstan. Seperti di otak, kebutuhan aliran darah dan laju metabolisme tinggi pada gray matter. Total aliran darah otak manusia adalah $50 \mathrm{~mL} /$ menit / $100 \mathrm{~g}$. Alur medula spinalis bervariasi, tergantung pada spesies dan luas medula medula yang diteliti. Suplai darah intrinsik tulang belakang berbanding lurus dengan area gray matter, dan ini paling melimpah di segmen torakolumbalis. Akibatnya, segmen ini mungkin lebih rentan terhadap hipoperfusi. Dalam serangkaian kasus infark sumsum tulang belakang, lokasi ini tetap yang paling sering terlibat, dan sumsum tulang belakang adalah lokasi yang paling sering terkena kedua pada $25 \%$ pasien. Aliran darah sumsum tulang belakang memiliki pola yang berbeda dalam sistem anterior dan posterior. Aliran di arteri tulang belakang anterior terutama kaudal dan searah. Infark kemungkinan besar terletak di distribusi arteri spinal anterior. Aliran di arteri spinal posterior adalah dua arah, kaudal di daerah serviks dan toraks, dan rostral di daerah lumbosakral. ${ }^{12,} 13$ Tujuan utama selama pemeliharaananestesi pada tulang belakang adalah untuk mempertahankan perfusi spinal yang memadai untuk mencegah kerusakan lebih lanjut. Jika ada gangguan bermakna pada autoregulasi, perfusi spinal tergantung pada perfusi sistemik, artinya hipotensi sistemik dapat menyebabkan cedera sekunder dengan mengurangi tekanan perfusi. Sebaliknya, hipertensi dapat menyebabkan perdarahan dan edema. Drainase cairan serebrospinal melalui kateter juga dapat dipertimbangkan untuk membantu meningkatkan tekanan perfusi tulang belakang. Hal ini dilakukan dengan mempertahankan tekanan arteri rata-rata 85-90 $\mathrm{mmHg}$ dan menghindari tekanan darah sistolik kurang dari $90 \mathrm{mmHg}$ selama lebih dari 5-7 hari dengan penggunaan intravena vasopressor dan inotropik. ${ }^{14,15}$

Pada posisi prone, dapat terjadi ulserasi kulit muka akibat dari distribusi tekanan yang tidak rata ketika menggunakan head rest, dan dapat terjadi kebutaan akibat tekanan pada bola mata. 
Neuropati optik iskemik dihubungkan dengan prosedur operasi yang lama pada posisi prone walaupun tidak ada tekanan langsung pada bola mata. Faktor risiko yang dihubungkan dengan keadaan ini adalah perdarahan, anemia dan hipotensi. Pengaturan posisi dilakukan dengan sebaik mungkin untuk menghindari cedera. Kepala yang ekstensi dapat meningkatkan tekanan vena serebral. Kepala dan leher diatur sedemikian rupa untuk mencegah tekanan yang berlebihan pada mata dan hidung, serta mencegah rotasi yang berlebihan pada leher. Diketahui bahwa rotasi leher $60^{\circ}$ dapat menurunkan aliran darah arteri vertebralis dan karotis. Bahkan, aliran arteri vertebralis akan terhenti bila rotasi leher mencapai $80^{\circ}$. Ekstremitas superior kiri dan kanan diatur dengan sedikit fleksi anterior, abduksi dan rotasi eksternal $<90^{\circ}$. Posisi prone dapat menghindari masalah emboli udara yang mungkin terjadi pada posisi duduk. Hati-hati terhadap penyangga kepala, karena beratnya kepala pada orang dewasa dapat menyebabkan nekrosis akibat tekanan pada daerah frontal dan kebutaan karena trombosis arteri retina. Telah dilaporkan adanya perubahan kardiovaskular pada posisi ini, termasuk penurunan curah jantung, stroke volume, dan indeks jantung. Perhatian khusus pada jalan napas karena ada risiko tercabutnya pipa endotrakhea. Penempatan lengan pasien di sisi tubuh harus hati-hati supaya tidak ada penekanan pada saraf. ${ }^{16,17}$

Pasien ini menjalani VP-shunt 2 minggu sebelumnya oleh karena adanya hidrosefalus. Adapun pertimbangan patofisiologi umum dalam pediatrik neuroanestesi antara lain basic tubular dan multi ventrikel terbentuk saat trimester pertama, tetapi koneksi neural, struktur pendukung dan mielinisasi terjadi pada semester akhir. Pertumbuhan itu membutuhkan banyak oksigen sehingga bila terjadi hipoksia atau iskemia akan terjadi mikrocephali dan defisit neurologis. Tugas utama pada neuroanestesi pediatrik adalah mengontrol intracranial pressure (ICP). Perbedaan karena anatomi, fisiologi, dan psikososial pada anak, menyebabkan perbedaan dalam penanganan baik pada pemeriksaan, penegakkan diagnosa, penggunaan alat-alat dan obat-obatan, sehingga menjadi suatu masalah khusus dalam neuroanestesi. Pada anak lebih mudah terjadi trauma kepala karena kepala lebih besar dibandingkan dengan badan yang secara gravitasi kepala lebih duluan kena benturan, tulang kepala lebih tipis yang mengurangi proteksi isi tengkorak. Jaringan neural yang sedikit mengandung mielin yang menyebabkan jaringan saraf mudah rusak, pada anak lebih sering terjadi cedera yang difus dan edema otak, dan peningkatan tekanan intrakranial lebih mudah terjadi. Disamping juga terdapat perbedaan dalam fisiologi respirasi dan sirkulasi pada anestesi anak umumnya.

Perbedaan perkembangan krikotiroid dan percabangan trakea memberikan pengaruh yang bermakna untuk manajemen jalan napas pada pasien anak. Laring pada bayi dan anak berbentuk funnel shaped, dengan bagian tersempit setinggi krikoid, dimana ini merupakan bagian jalan napas anak yang paling kecil. Hal ini membuat anak memiliki resiko untuk mengalami obstruksi subglotik sekunder akibat edema mukosa karena penggunaan intubasi endotrakeal yang lama dengan pipa endotrakeal yang ukurannya pas di trakea. ${ }^{19}$ Jalan napas harus diamankan dengan pipa endotrakeal dengan ukuran yang tepat dan dilakukan pernafasan terkontrol. Intubasi dapat dilakukan dengan menggunakan pelumpuh otot atau anestetik lokal (lignokain 1\%) secara topikal pada laring. Prosedur bedah pengangkatam tumor thorakal posterior digunakan posisi prone. Trakea relatif lebih pendek, fleksi leher dapat menyebabkan migrasi pipa endotrakeal ke dalam cabang bronkus utama atau obstruksi vena jugularis yang mengganggu drainase vena dan meningkatkan volume serta tekanan intrakranial. Perhatian ekstra untuk mengamankan pipa endotrakeal harus dilakukan pada posisi ini. Ahli anestesi harus melakukan auskultasi pada kedua lapangan paru untuk memastikan pipa endotrakeal tidak mengalami migrasi. ${ }^{18,19}$ Perawatan pascaoperasi pada pasien ditentukan oleh kompleksitas prosedur operasi dan perubahan fisiologi yang terjadi selama tindakan. Prosedur operasi intrakranial dan kasus-kasus neurologi berat lainnya membutuhkan perawatan di Pediatric Intensive Care Unit. ${ }^{19}$ 


\section{Simpulan}

Malnutrisi masih merupakan masalah kesehatan pada anak di Indonesia sehingga diperlukan kewaspadaan pada saat operasi. Penanganan malnutrisi kronik dalam tahapan fase stabilisasi, fase transisi, fase rehabilitasi dan fase tindak lanjut untuk mengatasi syok dengan gizi buruk, infeksi, dan anemia berat. Stress operasi mengeluarkan hormone kortisol, glukagon, katekolamin dan menurunnya insulin sehingga terjadi keadaan hiperglikemik. Malnutrisi kronis lebih banyak terjadi pemecahan protein dan lemak mengakibatkan protein yang beredar dalam darah sedikit sehingga diperlukan dosis obat lebih kecil.

Posisi prone pada pediatrik menjadi tantangan tersendiri neuroanestesi secara optimal. Tujuan utama pemeliharaan anestesi pada tulang belakang adalah untuk mempertahankan perfusi spinal yang memadai untuk mencegah kerusakan lebih lanjut. Adanya perbedaan anatomi, fisiologi, dan psikososial pada anak, menyebabkan perbedaan dalam penanganan baik pada pemeriksaan, penegakkan diagnosa, penggunaan alat-alat dan obat-obatan, sehingga menjadi suatu masalah khusus dalam neuroanestesi. Tujuan dari laporan kasus ini untuk mendapatkan outcome yang terbaik dengan manajemen pediatrik neuroanestesi tulang belakang.

\section{Daftar Pustaka}

1. Susanto JC, Mexitalia M, Nasar S. Malnutrisi akut berat dan terapi nutrisi berbasis komunitas. Dalam: Syarif D, Lestari E, Mexitalia M, Nasar S, penyunting. Buku Ajar Nutrisi Pediatrik dan Penyakit Metabolik, jilid 1, cetakan I. Jakarta: Ikatan Dokter Anak Indonesia. 2011;128-45.

2. Batubara J, Susanto R, Cahyono $\mathrm{H}$. Pertumbuhan dan gangguan pertumbuhan anak. Dalam: Buku Ajar Endokrinologi Anak. Jakarta: Ikatan Dokter Anak Indonesia. 2015;29-32.

3. National Institute of Neurological Disorders and Stroke. 2005. Brain and Spinal Cord
Tumors - Hope Through Research. [serial online]. http://www.ninds.nih.gov [06 Maret 2019].

4. Willey JZ, Barnett HJM, Mohr JP. Spinal cord ischemia. Dalam: Stroke. Elsevier. 2011;643-57.

5. Wassia H, Shah P. Folic acid supplementation for the prevention of neural tube defects: promotion and use. Canada: Nutrition and Dietary Supplements Department of Pediatrics University of Toronto. 2010;2:105-16.

6. Dumont C, Lacrosse D, Simonet O, Schils JL, \& De Kock M. Why should the anesthesiologist evaluate nutritional status? Acta Anaesthesiologica Belgica. 2016;67(1): $16-28$.

7. Kazeem AO, Idowu OS. Pathophysiological changes that affect drug disposition in proteinenergy malnourished children. Nutrition \& Metabolism. December 2019.

8. Hill, Graham L. Buku Ajar Nutrisi Bedah (Disorder of Nutrition and Metabolism in Clinical Surgery Understanding and Management). New Zealand. 2013. Farmedia.

9. Takahiro Hayashi. Influence of serum albumin levels during opioid rotation from morphine or oxycodone to fentanyl for cancer pain. Department of Pharmacy, Fujita Health University Hospital.

10. Wiryana M. Nutrisi pada penderita sakit kritis. J Peny Dalam: 2007; 8 (2).

11. Soriono SG, Eldred GE, Rockoff MA. Pediatric neuro-anesthesia. Anesthesiology Clinic of North America;2002, 389-404.

12. Fransesco S, Albino B. Surgery for intramedullary spinal cord tumors: the role of intraoperative (neurophysiological) monitoring. Eur Spine J. 2007 Nov; 16(Suppl 2): $130-39$. 
13. Bisri DY, Bisri T. Anestesi untuk operasi tumor otak: supratentorial dan infratentorial. Bandung: Fakultas Kedokteran Universitas Padjadjaran, 2016.

14. Newton MC. Anesthesia for spinal surgery. Dalam: Essentials of Neuroanesthesia and Neurointensive Care. Philadelphia: Saunders Elsevier. 2008; 55-159.

15. Miller RD. Miller's Anesthesia. 6th ed. Pennsylvania: Elsevier Churcill Livingston; 2005

16. Hobbs AJ, Stirt JA. Pediatric neuroanesthesia. Dalam: Sperry RS, Stirt JA, Stone AJ, eds. Manual of Neuroanesthesia, 1st ed.
Philadelphia: Pensylvania, 1989; 183-204.

17. Vavilala MS, Chestnut R. Anesthesia considerations for pediatric neuroanesthesia. Dalam: Gupta AK, Gels AW, eds. Essential of Neuroanesthesia and Neurointensive Care, 1th ed. Philadelphia: Saunders Elsevier; 2008,192-201.

18. Kanonidou Z. Anaesthesia for chronic spinal cord lesions. Hippokratia. 2006;10:28-31.

19. Ibrahim S, Rosa AB, Harahap AR. Neurosurgery lecture notes. Medan: USU Press; 2012, 671-80. 